\title{
SATISFACTION OF RURAL POPULATION WITH PUBLIC SERVICES IN THE REGIONS: ANALYSIS OF EDUCATIONAL INDICATORS
}

Gediminas MERKYS, Board of the Association of Trade Unions of Lithuanian Higher Education Institutions, K. Donelaičio g 73 , LT - 44249, Kaunas, Lithuania; gediminas_merkys@yahoo.com (corresponding author)

Daiva BUBELIENE, Department of Social Work, Faculty of Medicine, Kauno kolegija/University of Applied Sciences, Pramonès 22A, Kaunas, LT - 50468, Lithuania; daivabubeliene@gmail.com

Nijolė ČIUČIULKIENĖ, Department of Philosophy, Psychology and Vocational education, Faculty of Economy and Administration, Aleksandras Stulginskis University, Studentu g. 11, Akademija, LT - 53361, Kaunas district., Lithuania, nijole.ciuciulkiene@asu.lt

The key idea of the well-being concept strives to answer the question about how well the needs of people in a society are met in different spheres of social life - the physical, economic, social, educational, environmental, emotional, and spiritual - as well as individuals' evaluations of their own lives and the way that their society operates (Gilbert, Colley, Roberts, 2016). One of the possible suggestions for answering the question: "How well are the needs of people in a society met?" could be the monitoring of citizen's satisfaction with public services while applying a standardized questionnaire for population covering 193 primary indicators (health, social security, culture, public transport, utilities, environment, recreation and sport, public communication, education, etc). Even 23 indicators are about education that makes educational services a considerable part of all social service system. As the researchers aimed to analyze satisfaction of rural population with public services stressing the education issue, indicators about education dominated in the survey. The data were collected in 2016 - 2017 in 2 regional municipalities: municipalities: Jonava and Radviliskis (N=2368). The results of the analysis demonstrate that rural residents' satisfaction with formal general education services is relatively high. The only negative exception is the "the placement of a child in a pre-school institution based on the place of residence". Furthermore, rural residents poorly evaluated educational services that are related to non-formal education, adult education, the education of children with disabilities, child safety, meaningful xtracurricular activities of children and young people during all day, preventive programs. These major conclusions let the researchers state that local self-governmental institutions are not capable to cope with the quality challenges of some educational services without special intervention policy of the central government and the EU responsible structural units. A negative impact is also reinforced by a rapidly deteriorating demographic situation in Lithuanian rural areas.

Keywords: rural development, societal monitoring, rural population satisfaction, educational service

\section{INTRODUCTION}

The concept of well-being is one of the mostly discussed, ambiguous and abstract concepts. Its multidimentional essence has been highlighted with numerous interpretations (Brown, Westaway, 2011; King, Renó, Novo, 2014; Gilbert, Colley, Roberts, 2016). General definitions of well-being, presented in dictionaries underline such aspects as a desirable state of being happy, healthy, or prosperous; that is, well-being refers to both: subjective feelings and experiences as well as to living conditions (Ben-Arieh, Casas, Frønes, Korbin, 2014). Moreover, the well-being concept reveals the main guidelines for societal monitoring as it tries to answer the question about how well the needs of people in a society are met across various domains - the physical, economic, social, environmental, emotional, and spiritual (Gilbert, Colley, Roberts, 2016). Broadly defined, the objective components of well-being include many material and social attributes of people's life circumstances such as physical resources, employment and income, education, health, and housing. The quality level of these components may be monitored with the help of the official statistics, whereas the subjective level of the well-being understanding may be researched only with the help of different surveys, giving the respondents the possibility to evaluate personally the experience of their well being.

The efforts to measure community satisfaction level have never lost their relevance as they are directed towards the development of a systematic approach to societal monitoring. The presented research also aims to complement to this approach while investigating satisfaction of rural population with educational public services as education is tightly connected with such aspects of well-being as opportunities for the personal development and self-fulfillment (Ben-Arieh, Casas, Frønes, Korbin, 2014; Ben-Arieh,).

It is symptomatic that in Lithuania the majority of educational institutions are established by a local municipality. Therefore, educational services (with the exception of certain cases), are provided and paid by the state. The average of

Copyright (C) 2017 The Authors. Published by Aleksandras Stulginskis University. This is an open-access article distributed under the terms of the Creative Commons Attribution License (CC-BY 4.0), which permits unrestricted use, distribution, and reproduction in any medium, provided the original author and source are credited. 
the dotations assigned by municipalities to their educational services reaches $50 \%$. (!) of the local budget. No other public service provided by municipalities takes up such a relatively large share in the structure of the budget. Here comes to surface the problem: the official governmental necessity to control the quality of educational services and the fairness of the data that are reported to taxpayers and the founder about how well the public money allocated to educational services is spent. The resolution of the problem may be reached while fulfilling two objectives: firstly, reasoning the relevance of the survey based on educational indicators, considering them as a tool for reporting the data on educational services quality which arise the satisfaction of rural population with educational public services; secondly, presentation of the analysis of the received data and the consequent discussion, highlighting peaks and pits of educational services in rural municipalities. The research has been carried out in a quantitative paradigm. The main framework of the research is the construction of educational indicators, the or a composition of the survey, analysis of the received data with the help of statistic analysis.

\section{Educational indicators as a tool for reporting the satisfaction of rural population with educational services quality}

In the framework of modernity, in the context of the so-called "felicitarial" economy (Navaitis, 2013), where people are striving for ideological goal as well, the subjective quality of life and real human satisfaction (Merkys, Brazienè, 2009) are of primary importance. In recent years, mandatory procedures of quality assurance and selfassessment have been introduced in Lithuania, the so-called "internal audit", "external audit" and "accreditation" are periodically performed at schools. The Ministry of Education and Science of the Republic of Lithuania regularly publishes statistical issues and ranking data on educational quality indicators of educational institutions. Having in mind the supposed positive contribution of such quality control procedures, the above-mentioned actions are partly based on bureaucratic model and bureaucratic rationality. Unfortunately, they often reflect not so much the real quality of educational work, but the ability of an institution to fine-tune paper, communicate smoothly with authorities and controlling institutions. Moreover, the credibility of the quality of educational services is not always possible even with a seemingly reliable and objective source such as Official Statistics. In addition to the previously mentioned methods and sources of getting information about the quality of educational services, surveys of consumer satisfaction with public services are more and more relevant. They may be performed while relying on the survey method (Braziene, Merkys, 2015; Merkys, 2016).

\section{RESEARCH METHODOLOGY AND THE DESIGN}

Research methodology is centered around a standardized questionnaire for population covering 193 primary indicators, which measure satisfaction with various public services: health, social security, culture, public transport, utilities, environment, recreation and sport, public communication, education, etc. The methodology projects the following quantitative aspects: the percentage of service benchmarking and the percentage of ranked service (PR) in the rate of 193 positions. The advantage of the methodology is that it transforms the indicators, which are not comparable in terms of conceptual and official statistics, into relatively homogeneous indicators of opinion. The latter can already be compared and ranked. The methodology is very functional when it comes to identifying: (a) those public services that are subjectively perceived as poor, good or medium; b) it is necessary to look at the satisfaction of the services of a particular sector in different district areas, towns and villages. The aim of the research is while using the methodology on the satisfaction of rural population with public services to highlight the analysis of 21 educational indicators.

The latest data were collected in 2016-2017 in regional municipalities of Jonava and Radviliskis (Merkys, 2016; Merkys, Bubeliene, 2017). A total sample of respondents in the above-mentioned municipalities is 2368 ( $N=2368$ ). In the case of educational indicators, the statistical regularities, which are typical for all the municipalities under investigation, were determined. The results of the analysis show that: 1) rural residents' satisfaction with formal general education services is relatively high. The only negative exception is the "the access to a child's place in a pre-school institution based on the place of residence"; 2) rural residents poorly evaluated educational services that are related to non-formal education, adult education, the education of children with disabilities, child safety, meaningful occupation of children and young people during all day, preventive programs. These major conclusions let to state that local self-governmental institutions are not capable to cope with the quality challenges of some educational services without the central government and the EU's special intervention policy. A negative impact is also reinforced by a rapidly deteriorating demographic situation in Lithuanian rural areas.

The statistical database on educational indicators (see Table 1) was obtained while using an inventory type survey. A standardized questionnaire has been developed since 2001. Reference was made to the "social indicators"; The concepts of "quality of life" and "satisfaction with public services" (Merkys, Brazienè, 2009; Brazienè, Merkys, 2015). During the latter years, dozens of studies were carried out in the municipalities of the country, in some municipalities the survey was periodically repeated 3-6 times. The structure of the primary indicators is well-established and includes 193 items. The latter, while combining the logic and factor validation are distributed into 38 subscales and 8 scales.

The questionnaire covers, to a large extent, all indicators of public services that are generally provided by municipalities in Europe. Out of the 193 indicators, 21 (or 10.9\%) are indicators that are attributable to the educational sphere. The cluster of educational indicators is of sufficient size to be considered as a separate object.

For each primary item, a typical 5-step standard response format is provided. These are two disadvantaged, twofavored-service assessment grades, and the middle one - "I do not have opinions" or "I do not know. The rates of the two favorable rating categories are combined in the Likert scale on the "yes percentage" (Borg \& Gabler). The advantage of 
the methodology is the fact that the indicators are very different from the conceptual and thematic point of view, and at least from the point of view of official (state) statistics, indicators are converted into homogeneous and directly comparable indicators of opinion on services.

Table 1. Educational service indicators, the rating starts with the most favored service

\begin{tabular}{|c|c|c|c|c|c|c|c|}
\hline \multirow[b]{2}{*}{ R/No. } & \multirow[b]{2}{*}{ Education and Culture } & \multicolumn{2}{|c|}{ Radviliškis } & \multicolumn{2}{|c|}{ Jonava } & \multicolumn{2}{|c|}{$\begin{array}{c}\text { Cluster } \\
\text { Membership }\end{array}$} \\
\hline & & $\begin{array}{c}\text { Yes } \\
\%\end{array}$ & PR\% & Yes\% & $\begin{array}{c}\text { PR } \\
\%\end{array}$ & $m$ 章 & + 气 \\
\hline 1. & $\begin{array}{l}\text { The quality of the services provided in pre-primary education } \\
\text { institutions }\end{array}$ & 69,8 & 92,8 & 62,1 & 82,3 & 1 & 1 \\
\hline 2. & $\begin{array}{l}\text { The quality of giving pupils a lift service (yellow and school } \\
\text { buses, local buses) }\end{array}$ & 65,2 & 90,7 & 62,6 & 88,5 & 1 & 1 \\
\hline 3. & $\begin{array}{l}\text { The quality of the services provided in general education } \\
\text { schools }\end{array}$ & 66,2 & 87,6 & 59,2 & 75,5 & 1 & 1 \\
\hline 4. & $\begin{array}{l}\text { The diversity of children's extra-curriculur institutions (arts, } \\
\text { music, sports schools, colleges, etc.) }\end{array}$ & 62,9 & 85,5 & 57.8 & 78,4 & 1 & 1 \\
\hline 5. & The quality of services provided by extra-curriculur institutions & 59,8 & 82,9 & 52,0 & 75,0 & 1 & 1 \\
\hline 6. & $\begin{array}{l}\text { The existing network of general education schools ( adequacy } \\
\text { and accessibility of schools for children) }\end{array}$ & 61,7 & 80,3 & 66,6 & 85,7 & 1 & 1 \\
\hline 7. & $\begin{array}{l}\text { Variety and quality of extracurricular activities organized by } \\
\text { school }\end{array}$ & 54,8 & 74,1 & 50,2 & 67,4 & 2 & 2 \\
\hline 8. & Child / schoolchild security in educational institutions & 55,5 & 73,1 & 44,5 & 48,4 & 2 & 2 \\
\hline 9. & $\begin{array}{l}\text { The existing network of pre-school education institutions } \\
\text { (adequacy, availability, possibility to get a place) }\end{array}$ & 53,6 & 67,9 & 56,0 & 70,3 & 2 & 2 \\
\hline 10. & The quality of the services provided at the youth school & 43,6 & 66,8 & 44,6 & 63,0 & 2 & 2 \\
\hline 11. & $\begin{array}{l}\text { Availability and accessibility of children's out-of-school } \\
\text { establishments }\end{array}$ & 50,9 & 66,3 & 47,9 & 63,0 & 2 & 2 \\
\hline 12. & The quality of vocational training & 41,1 & 60,1 & 41,0 & 51,0 & 2 & 2 \\
\hline 13. & Activities of children's and youth organizations & 42,4 & 57,0 & 42,8 & 51,0 & 2 & 2 \\
\hline 14. & Organization of the employment of children and youth & 44,3 & 56,5 & 47,1 & 54,2 & 2 & 2 \\
\hline 15. & Adult non-formal education status in the district & 38,9 & 50,3 & 36,2 & 28,3 & 3 & 3 \\
\hline 16. & The situation of children with disabilities & 38,4 & 49,2 & 32,1 & 31,0 & 3 & 3 \\
\hline 17. & $\begin{array}{l}\text { The role of non-governmental organizations active in the region } \\
\text { in working with children and young people }\end{array}$ & 39,5 & 43,0 & 35,9 & 36,2 & 3 & 3 \\
\hline 18. & The effectiveness of school bullying prevention programs & 35,2 & 27,5 & 30,5 & 18,2 & 3 & 4 \\
\hline 19. & Possibility of acquiring a profession without leaving the district & 31,5 & 21,2 & 39,7 & 34,6 & 3 & 4 \\
\hline 20. & $\begin{array}{l}\text { The state of re-qualification and adult education in the } \\
\text { subdistrict / district (possibility to get a new profession, attend } \\
\text { various courses }\end{array}$ & 26,2 & 16,1 & 29,4 & 18,2 & 3 & 4 \\
\hline \multirow[t]{3}{*}{21.} & The state of education and resocialization of juvenile offenders & 25,1 & 16,6 & 22,2 & 6,3 & 3 & 4 \\
\hline & Variation scope & 44,7 & 76,7 & 43,9 & 82,2 & & \\
\hline & Mean & 47,9 & 60,3 & 45,7 & 53,6 & & \\
\hline
\end{tabular}

Such approach enables to form a general rate of service indicators, whereas a high number of primary indicators ( $\mathrm{N}$ indicator $\approx 200$ ) allow a meaningful calculation of such index as a percentage ranking of service indicator. The latter is compiled from the Likert scale averages. The modal value, distribution, and other measurements, for example, percentage frequencies of service estimates as "favorable", "unfavorable" and "neutral" can be also calculated. These indicators are sufficient to provide an overview of the service indicator rating.

Still, the methodology has some limitations. It is obvious that the semantics of the middle category of response include two though related, but not entirely identical evaluation categories. Such expressions as "I know the service well, but as I evaluate it satisfactory "; "I evaluate the service with the index 'I do not know', 'I do not have an opinion', because I have no experience with the service"leads to a polarized differentiation of the service rankings: only very poorly and very well-evaluated service indicators can be precisely ranked.

The center of the of service indicators ranking is diagnostically less eloquent since it is difficult to distinguish whether the educational service was evaluated satisfactory or there simply was not enough information about it because the majority of the consumers have never come across the above-mentioned service. However, the advantage of such limitation is that one can create a ranking of services and psychometric scales. Subsequently, while comparing the estimates of service evaluation in different socio-demographic groups and locations, it is possible to determine roughly whether the service is well-known or moderate. The wide spread of the feature in a variety of locations and in socio-demographic groups indicates the tendency of a service to be judged on average. 


\section{Dendrogram using Average Linkage (Between Groups)}

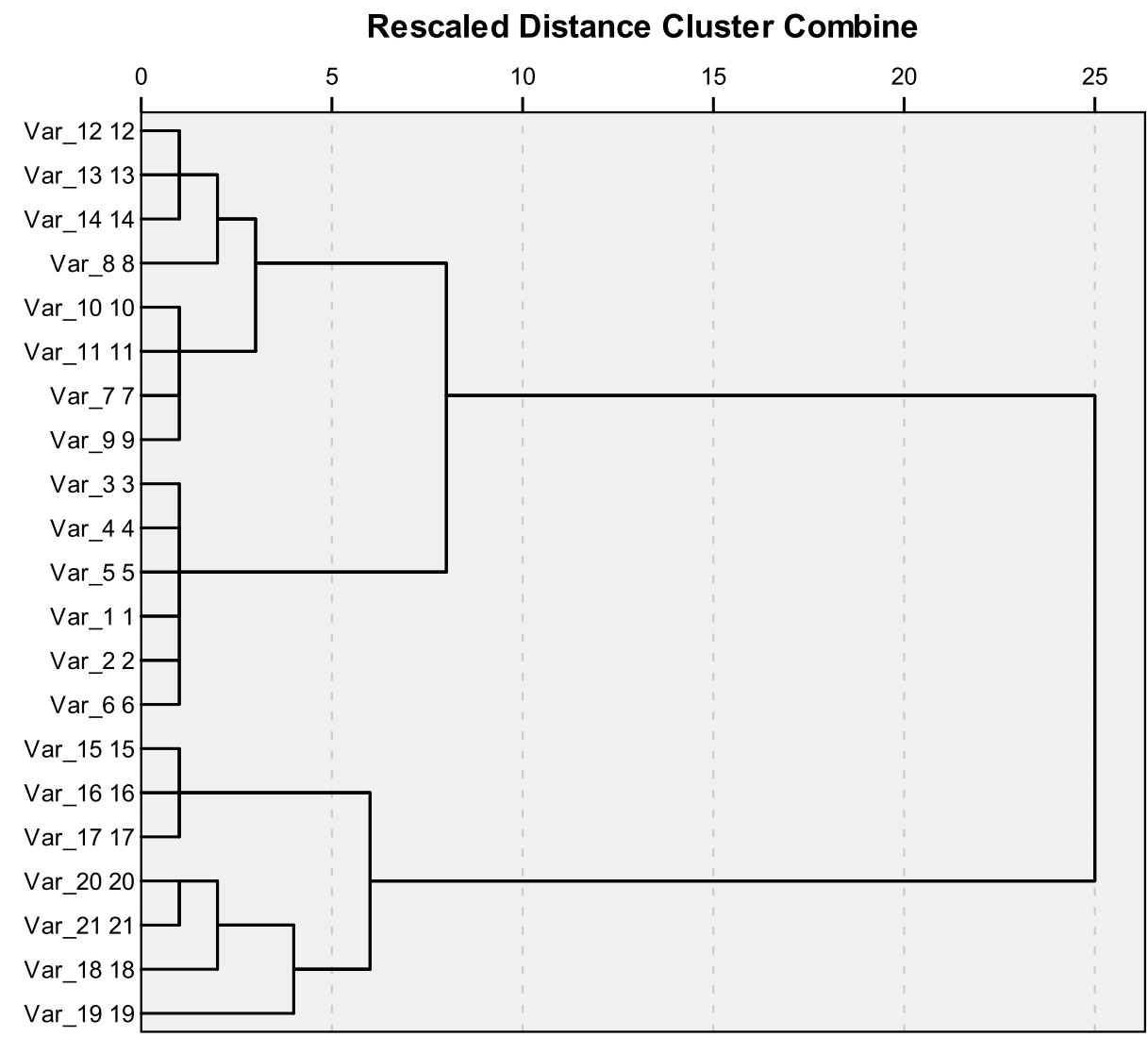

Figure 1. Clastirization of educational indicators

The estimates of educational indicators in this article are taken from 2 municipalities of Lithuania - Jonava and Radviliškis districts. The samples of respondents are relatively high for the evaluation of the fluctuation of service satisfaction indicators in separate municipal areas and in separate socio-demographic groups. (N Radviliškis $\sim 1333$; N Jonava 1035). The age of the respondents was not restricted to the upper age limit of 18, both municipalities have about 40 thousand inhabitants. The possible error of the questionnaire is calculated by the maximum spread method, with the statistical significance level $\alpha=0.05$, respectively reaches 2.6 and 3.0 percent. Surveys were conducted in 2016-2017. Up to $30 \%$ of respondents in each municipality were questioned online; remaining respondents were questioned using the traditional paper-pencil-test method.

\section{RESULTS AND DISCUSSION}

The results of the service indicators rating by municipalities are reflected in Table 1. Radviliskis district education indicators were taken as a basis for ranking. The Table1 shows the percentage of service benchmarking and the percentage of service indicator in that municipality. The ranking correlations were found between: a) percentages of approval ratings in both municipalities; and b) an analogy between the percentile rows. In both cases the Spearmen 'rho coefficients are very high, respectively 0.94 and 0.93 . This shows that the ratings of educational services indicators found in different geographically distant municipalities are rather identical. The extent of approval percentages and percentage ranges within the same municipality is quite high. This indicates that the rating of educational services indicators is not a formal statistical artifact, it is necessary to discuss the real differences in the evaluation of educational service indicators. In our opinion, the percentage of the educational service indicators is particularly prominent in a diagnostic sense because it shows how one or another educational service is evaluated in the context of all indicators of the public service provided by the municipality. The distance between the highest and the worst evaluated educational indicators in Radviliškis district is 76.7, analogous to Jonava district 82.2 per cent.

The analysis of the educational service indicators rating is a trivial, routine procedure. Nevertheless, in a number of cases, the ranking almost coincides with the estimates of neighboring positions. This means that the values of adjacent service indicators (for example, percentiles or "yes-percentages" fall into the same confidence interval). Therefore, the decision which percentage rank out of all empirically accumulated function of frequencies should be marked as a criterion is no longer trivial. In other words, it is not quite clear, which point to the function should be considered a threshold from which the relatively high rated educational services go to the average and poorly valued services. 


\section{Proceedings of the $8^{\text {th }}$ International Scientific Conference Rural Development 2017}

In order to perform such classification, hierarchical cluster analysis (Between Groups Linkage, Distance Measurement: Squared Euclidean Distance) was used. The educational indicators were grouped on the basis of four variables. It means that there were taken positive evaluation percentages and percentage rankings of the service indicators that were common for both municipalities. There has been received a rather characteristic, clearly interpreted dendrogram (see Figure 1). It shows that there are meaningful models of three and four clusters. The standard 25-pixel scale indicates that both cluster patterns are formed very early: the four cluster model is formed even at the fourth standard scale, and the three-cluster model is formed roughly at the seventh standard scale. This shows that the primary variables within the cluster are very similar to their estimates. It is even possible to avoid the analysis of individual primary items and consider them 'in coropore' as a homogeneous group of educational services. The dependence of primary educational indicators to cluster models 3 and 4 is reflected in Figure 1.

It is reasonable to start the discussion with the characteristics of the investigated regions. The two regions investigated are typical rural municipalities of the optimal size, which are not attributable to the metropolitan cities (there about 5 rural municipalities from all 60 municipalities in Lithuania that are attributable to the metropolian cities). In the small municipalities of the composite type, approximately half of the inhabitants usually concentrate in the center of the district, and the remaining half are scattered in the rural type territory surrounding the district center as the geographical ring. It is possible to formulate a hypothetical assumption that these two municipalities selected for the survey are typical representatives of many municipalities in the country.

The data demonstrate positive aspect that at least the most important educational services are positioned in the fourth quartile and even much higher. Among them there are educational indicators such as: the quality of secondary and pre-school education, as well as the quality of post-secondary education. This optimistic issue faces the controversial challenging reality inspired by a demographic crisis in Lithuania. Migration dynamics is so intensive that some municipalities have to shut down schools, reduce the network of educational institutions Here comes to rescue the educational services, such as giving pupils a lift service (yellow and school buses, "mycrics", local buses) An overall assessment of pupil transfer system shows that peripheral municipalities are able to cope with heavy migration challenge and the results are quite high.

These findings enable us to formulate at least some universal generalizations. To begin with, Lithuania at least can partly justify the considerable budget allocations assigned to education. Furthermore, empirical findings at least partially supports the traditional postulates of the stereotyped concept concerning rural-urban differences - there is less social welfare in the village, and public services are relatively of the lower level than in urban districts. On the other hand, the data of PIRLS, PISA, TIMSS studies demonstrate that the achievements of rural pupils are far more (if not drastically) modest in comparison with urban schoolchildren. It is also necessary to mention the possibility that peripheral and village residents are generally less pretentious about the quality of all public services, including education. On the other hand, in rural districts, there are a number of gymnasiums, high schools with outstanding achievements.

It is interesting that the "mass consciousness" approach to the quality of education services and the satisfaction with them at this time coincides with that perception that stems from objective official statistics and expert knowledge. The rural residents were strikingly precise while evaluating the indicators dealing with education. For example, the very quality of a public service is evaluated very favorably and deservedly. The major target of critics is the availability of the service, for example, the possibility of obtaining a place for the child according to the residential area. This corresponds to the factual reality and is correctly mirrored in the EU statistics. According to the data of including 2-4 year Lithuania's children in pre-school education in the last few years, Lithuania is nearly at the end of all European Countries. Rural municipalities themselves are unable to solve this problem. There is not only a need of subsidiary investment but also the establishment of innovative legislation, which would open the possibility for the functioning of a typological diversity of pre-school education institutions, for example, community, street kindergarten, kindergarten for cooperated families, ect.

It is common knowledge that, during the boom of the establishment of elite gymnasiums and a massive expansion of higher education in Lithuania, vocational education has been desperately forgotten for decades. The need to correct the situation in government structures has only recently come to consideration. Another sphere of educational services which is totally neglected by the government is the adult education. For several decades, the "LLL" slogan is repeated as a mantra, but there is still no effective adult education in the country. In this area, first of all, there is a lack of intercourse between ministries and departments of education, social affairs, economy, health, and culture. Interministerial and interdepartmental miscommunication still remains the educational "Achilles heel" of Lithuanian governance.

Furthermore, it is generally known that there is currently no single children's and youth organizations in the country that would meet at least some of the essential requirements: a) multiplicity and availability, b) active and vital sections in the rural districts; (c) regular state support, at least on the basis of specific projects. The problem of socialization of juvenile delinquents and young people who tend to illegal behavior has no delicate solutions as well. During the demographic crisis this specific cohort (statistical group) has simply desperately shrunk, rolled in smart technologies and simply avoid reporting about themselves to the society.

Access to pre-primary education, vocational training, and adult education, the empowerment of children and youth organizations, the inclusion and re-socialization of adolescents are the burning issues that may be considered as insurmountable by a single rural municipality. The same could be said about the educational services to people with disabilities. Solution of these problems may be introduction of required interventional central government programs. In order to make a break through in these problematic areas, it is necessary not only to increase the amount of public funds, but to establish the innovative legislation, breakdown the interministerial, interdepartmental barriers, stimulate orientation 
to specific problems. The quality of work of news agencies, politicians, and officials must be judged not only on the basis of the results actually achieved, but also according to the subjective satisfaction of the public service users.

\section{CONCLUSIONS}

1. Bureaucratic model, bureaucratic rationality, and bureaucratic quality assurance procedures not always reflect the real quality of educational work. The credibility of the quality of educational services is not always possible even with a seemingly reliable and objective source such as Official Statistics. For this reason, surveys of subjective consumer satisfaction with public services are more and more relevant.

2. The analysis of educational indicators has been chosen in order to transform them into relatively homogeneous indicators of opinion which can be compared and ranked thus obtaining more comprehensive data on satisfaction of rural population with public services in the regions. The data analysis showed that:

2.1. the "mass consciousness" approach to the quality of education services and the satisfaction with them coincides with that perception that stems from objective official statistics and expert knowledge;

2.2. the received data demonstrate citizens' positive attitude to the quality of secondary and pre-school education, as well as the quality of post-secondary education;

2.3. the major critical issues are: the availability of the service, for example, the possibility of obtaining a place for the child according to the residential area, situation at vocational education, adults education, inclusion of juvenile delinquents into social life, educational programs for disabled persons;

2.4. in order to make a break through in these problematic areas, it is necessary not only to increase the amount of public funds, but to establish the innovative legislation, breakdown the interministerial, interdepartmental barriers, stimulate orientation to specific problems. The quality of work of news agencies, politicians, and officials must be judged not only on the basis of the results actually achieved, but also according to the subjective satisfaction of the public service users;

2.5. the balance between positive and negative subjective evaluations allows to state that Lithuania can really justify the considerable budget allocations assigned to education.

\section{REFERENCES}

1. Ben-Arieh, A., Casas, F., Frønes, I., Korbin, J.E. 2014. Multifaceted concept of child well-being. In Handbook of child well-being. Springer Netherlands, pp. 1-27. https://doi.org/10.1007/978-90-481-9063-8_134

2. Ben-Arieh, A., 2014. Social policy and the changing concept of child well-being. The role of international studies and children as active participants. Zeitschrift für Pädagogik, Vol. 60, no. 4, pp. 569-581. [In German]

3. Brazienè, R. Merkys, G. 2015. Viešųų paslaugų vartotojų pasitenkinimo indekso metodikos taikymas Lietuvoje. Viešoji Politika ir Administravimas, 2015, Vol. 14 Iss. 1, p. 103-114. [In Lithunian]

4. Brown, K., Westaway, E. 2011. Agency, capacity, and resilience to environmental change: Lessons from human development, well-being, and disasters. Annual Review of Environment and Resources, Vol. 36,(1), pp. 321-342. https://doi.org/10.1146/annurev-environ-052610-092905

5. Gilbert, A., Colley, K., Roberts, D. 2016. Are rural residents happier? A quantitative analysis of subjective wellbeing in Scotland. Journal of Rural Studies, Vol. 44, pp. 37-45. https://doi.org/10.1146/annurev-environ-052610-092905

6. King, M. F., Renó, V. F., Novo, E. M. 2014. The concept, dimensions and methods of assessment of human well-being within a socioecological context: a literature review. Social indicators research, Vol. 116(3), pp. 681-698. https://doi.org/10.1007/s11205013-0320-0

7. Merkys, G. 2016. Jonavos rajono gyventojų nuomonės tyrimas: viešųų paslaugų vartotojų pasitenkinimo indekso nustatymas. Avialable at: https://www.jonava.lt/documents/10156/856995/Apklausa+vie\%C5\%A1os+paslaugos.PDF/7dcca749-9675-4a79aca7-b6fbad7bfda9 [In Lithuanian]

8. Merkys, G., Brazienè, R. 2009. Evaluation of public services provided by municipalities in Lithuania: an experience of applying a standardized survey inventory. Social Sciences = Socialiniai mokslai, No. 4(66), pp. 50-61.

9. Merkys, G., Bubelienè, D. 2017. Radviliškio rajono gyventojų nuomonės tyrimas: viešųų paslaugų vartotojų pasitenkinimo indekso nustatymas. Ataskaita. [In Lithuanian]

10. Navaitis, G. 2013. Laimes ekonomikos ir felicitarines politikos perspektyva Lietuvoje. Socialinis darbas, Vol. 12(1), pp. 21. [In Lithuanian] 